\title{
Transformation of Villas to Mosques Social Impact of Islamization On The Government Center of Java In The Late $20^{\text {th }}$ Century
}

\author{
Muh Saerozi ${ }^{1}$ \\ 1 State Institute of Islamic Studies (IAIN) Salatiga, Indonesia
}

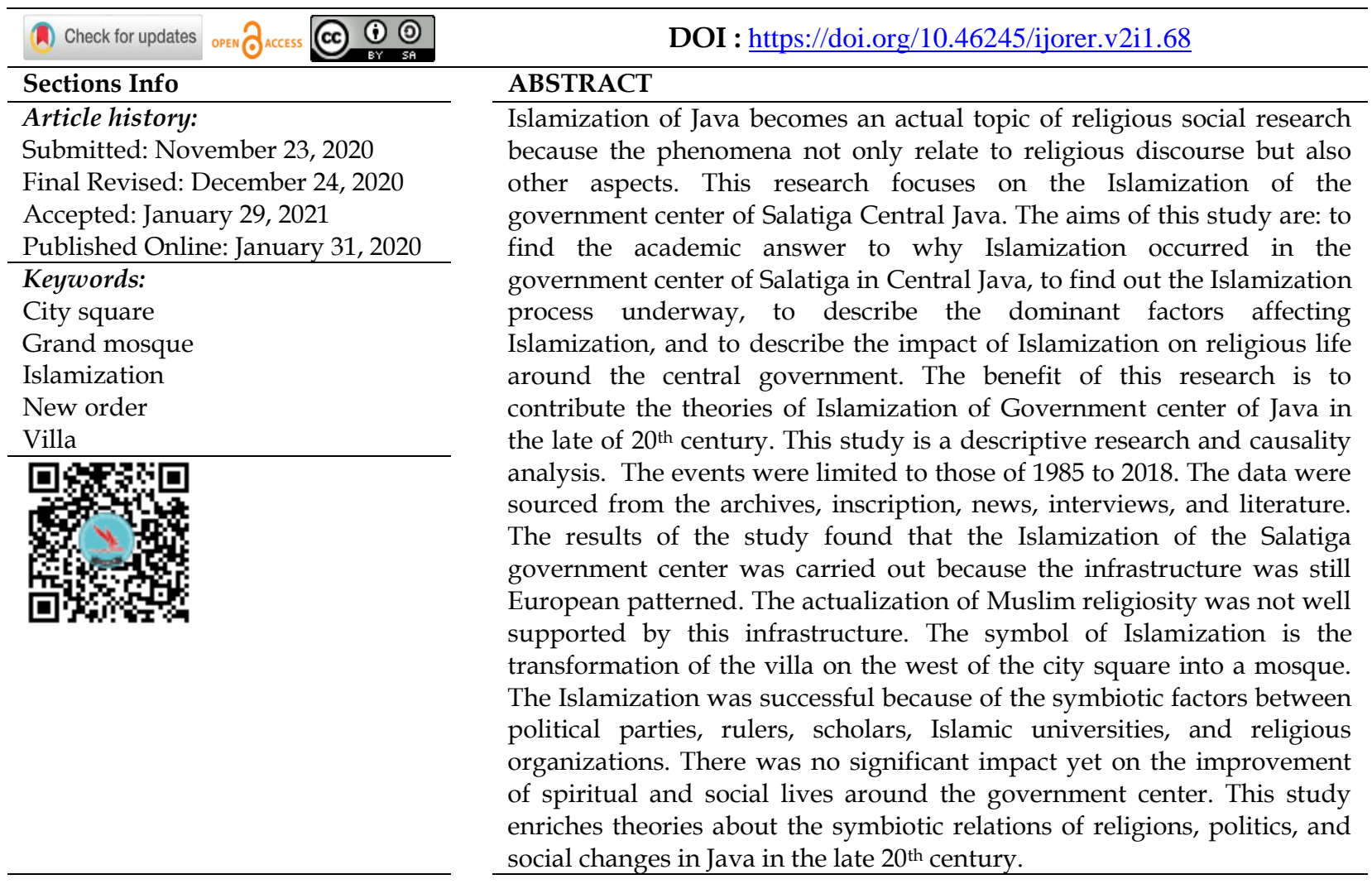

\section{INTRODUCTION}

Islamization becomes an actual topic of research in several countries because the phenomena relate to not only understanding the religious teaching but also other aspects. Omar (2017) correlates Islamization with income inequality and economic growth nexus in Malaysia. In fact, Islamization is actual and sensitive phenomenon in Indonesia. According to Azra (2013) Islamization in Java has not stopped, but is still ongoing. The process of Islamization in the past with the changes in it has become a remarkable example in increasing Islamic religious tolerance in the present. One of the symbols of Islamization in Java is the mosque at the government center (Tjandrasasmita, 2000). Historically, this phenomenon has been found in several cities in Central Java, East Java and Yogyakarta. The mosque is not only to facilitate daily prayers, but also to facilitate religious education, marriage, and the court (Pijper, 1985). Local authorities play a significant role in the functions of the mosque (Ashadi, 2017).

The phenomenon of Islamization in Java inspired the writer to examine the phenomenon in the government center of Salatiga, Central Java. There are several 
historical-sociological reasons for this inspiration. First, Salatiga in the Dutch colonial era had a smaller area than other municipalities in Central Java, but it became the center of the largest European community in Java. Second, the Dutch colonial government transformed the city of Salatiga from a traditional into a European standard city (Prakosa, 2017). The government center is equipped with a church, not a mosque like in other Muslim cities in Java. Third, the mosque was built at the end of the $20^{\text {th }}$ century.

Instead of historical-sociological reason, there is academic motive. To name of few, Myengkyo Seo - a researcher from the Department Malaysian-Indonesian Studies, an Overseas Study at Hankuk University, Seoul, Korea - wrote that the Pancasila field landscape does not only mean public space for the people of Salatiga City, but it also has religious significance (Seo, 2014). Benny Ridwan once described the sociological phenomena of the Darul Amal mosque in terms of the scientific categories of lecturers and worshipers (Ridwan, 2011)

Eddy Supangkat wrote a book about the old Salatiga Sketsa Kota (Supangkat, 2007), Galeria Salatiga (Supangkat, 2017), Istana Djoen Eng (Supangkat, 2017), and Gedung Pakuwon (Supangkat, 2017). Abel Jatayu Prakosa examined racial discrimination in Salatiga in 1917-1942 (Prakosa, 2017). Widiarto and Saparus wrote about the Salatiga treaty from a historical perspective (Widiarto \& Saparus, 2015). Agus Parmadi wrote about the Salatiga Struggle Monument in 1974 (Parmadi, 2013). T.M. Indah Harini wrote about the Utilization of Historical Artifacts from the Dutch Colonial Period in the City of Salatiga as a Source of Learning at Harini Middle School in 2010.

Referring to the previous literature, none has answered the question of the Islamization of the government center of Salatiga, so that the authors are motivated to research it. Some academic questions arise from the phenomenon of the Salatiga government center; (1) why did Islamization occur at the government center of Salatiga? (2) How did the Islamization process take place? (3) What are the dominant factors that influence Islamization? (4) What is the impact of Islamization on the religious life at the government center?

There are several objectives of this research namely finding the reason of Islamization of government center of Salatiga, the process of Islamization, the main factor affecting Islamization, and the impacts of Islamization towards social and religious life in government center. This research expects the theoretical contribution on Islamization of government center of Java in the late of $20^{\text {th }}$ century and provide additional literature on Islamization in Salatiga.

\section{RESEARCH METHOD \\ Research Goal}

This research is categorized as historical research because the object discussion is social phenomenon occurring in the past with different period (Wasino \& Endah, 2018). According to Kuntowijoyo (2008) the main elements of historical research are space and time, so the research context is limited in Salatiga Central Java from 1985 to 2018. The research not only descriptively explores the Islamization event, but also analyzes its causality and impact. 
Transformation of Villas to Mosques Social Impact of Islamization On The Government Center of Java In The Late $20^{\text {th }}$ Century

\section{Participants \& Data Collection}

Therefore, the data population method and analysis adapt the above scope. In this case, the method of data population applies informal interview, open observation, and written documentation (Moleong, 2014). The interview is conducted by involving historical actors, family, or close friends. Meanwhile, the observation focuses on the phenomena around the government center such as the events on town square, mosques, offices, shops, and food stall. In terms of documentation, it strives to find archives (letters, minutes of meetings, photos of activities, data statistic, inscriptions, news, and literature in Salatiga) such as documents at the Ministry of Religious office, the Salatiga Regional Government Archive Office or other institutions.

\section{Data Analysis}

The obtained data are thoroughly compiled based on the timeline, examined by external and internal criticism to meet its authenticity, and eventually constructed and communicated with simple, direct, and scientific language (Wasino \& Endah, 2018).

\section{RESULTS AND DISCUSSION \\ Pre-Islamization Conditions}

The infrastructure of Salatiga is now inseparable from urban planning policies in the Dutch colonial era. Salatiga City was arranged according to the pattern of cities in Europe because this city was the place chosen by the white people to rest and live. Salatiga was considered fertile, had fresh air, and was strategic for its defense and security (Prakosa, 2017). The population of Salatiga in 1905 was approximately 12,000. Of the total population, Europeans constituted 700 people, Chinese 1300, Arabic 7, and Bumiputra 9,993 (Prakosa, 2017). White people in Salatiga increased after this area was designated a municipality (de Gementee) on June 25, 1917 (Supangkat, 2007). In 1920, the number of white people was 1,208, Chinese 1,402 people, Arabic 71 people and Bumiputra 16,304. Some of the white people worked as plantation employees because there were 81 plantations throughout Salatiga in 1920. There was coffee, rubber, cocoa, cottonwood, quinine, spices, tobacco, wheat and vegetable plantations (Supangkat, 2007. Some of them also worked as teachers because the Dutch government established schools for European and Indo children in Salatiga (Prakosa, 2017). For example, the Eerste Europeesche Lagere School on the tuntang road (Toentangschweg) and Tweede Europeesche Lagere School in southern Blauran. In addition to setting up a government system, managing plantations, and managing schools, the white people in Salatiga also provided public facilities not yet known to Bumiputra residents. For example, asphalt roads, cobbled streets, sidewalks, city parks, tourist facilities, clean water, swimming pools, electricity, telephone, movie theaters, hotels, villas, banks, markets, hospitals, transportation, tree planting and cemeteries (Supangkat, 2007).

Settlements were arranged with public facilities. The colonial government arranged the settlements segregatively. The segregative pattern separated the population based on ethnicity or religion, so that the white people were separated from Bumiputra's settlement. Public facilities for indigenous peoples settlements were provided in a discriminatory manner (Prakosa, 2017). Segregative and discriminatory patterns are inherited from the strategy of VOC (Verenigde Oostindiche Compagnie) (Simbolon, 1995). Infrastructure development in Salatiga was accelerated in 1926 because the status of the 
city was upgraded to a fully autonomous region (stadsgementee) in accordance with the decentralization (desentralisatiewet) law in 1903 (Damayanti \& Handinoto, 2005). The city center of Salatiga was relocated from around the Kepatihan square (now the Pancasila Square) to the new location, in front of the house of the Assistant Resident (currently the Taman Sari roundabout) (Prakosa, 2017). The new city center is equipped with various facilities, such as a recreational park, a fountain, a clock monument, and an entertainment building. Although the city center was moved to a new location, the landscape of the old government center was not changed. Kepatihan square still exists with the banyan tree and the crossroads in the middle. To the south of the square still stands the Pakuwon building. To the north of the square the square still stands the building of the former Kepatihan office. Next to the Kepatihan office still stands the Patih Salatiga official residence. To the east of the square still stands the Central Java Christian Church (GKJTU). Across the church also still stands Papak building (Supangkat, 2007).

In the west of Salatiga square is not built any mosque, like in the Islamic city centers of Java, but the Vacantie Oord villa (Supangkat, 2007). The villa was built in 1919 for the purpose of resting travelers (Soediyono, 1986). Until August 1986, the layout of Salatiga government center did not change significantly. The position of the monumental buildings was still the same as before. Changes only occurred in aspects of functions and ownership. In the middle of the field, there was no crossroad according to the direction of the compass, but there was a circle made around the field in 1974. The Kepatihan Office changed its function to the Salatiga resort police station. Patih official house changed its function to a police dormitory. The church building still functions the same as a place of worship for the GKJTU congregation. Papak building has changed its function to the office of the mayor of Salatiga (Supangkat, 2007). The Pakuwon building functioned as a residence, and the Vacantie-Oord villa changed its function to a dairy and weaving company (Oetomo, 2017).

In 1982, the ownership of the former Vacantie-Oord villa changed from H. Asrori Arif to the Tarbiyah Faculty of IAIN Walisongo in Salatiga (Land Use Certificate, 1982). This building was used as the office of the Dean of the Tarbiyah Faculty of IAIN Walisongo in Salatiga (Subadi, 2018).

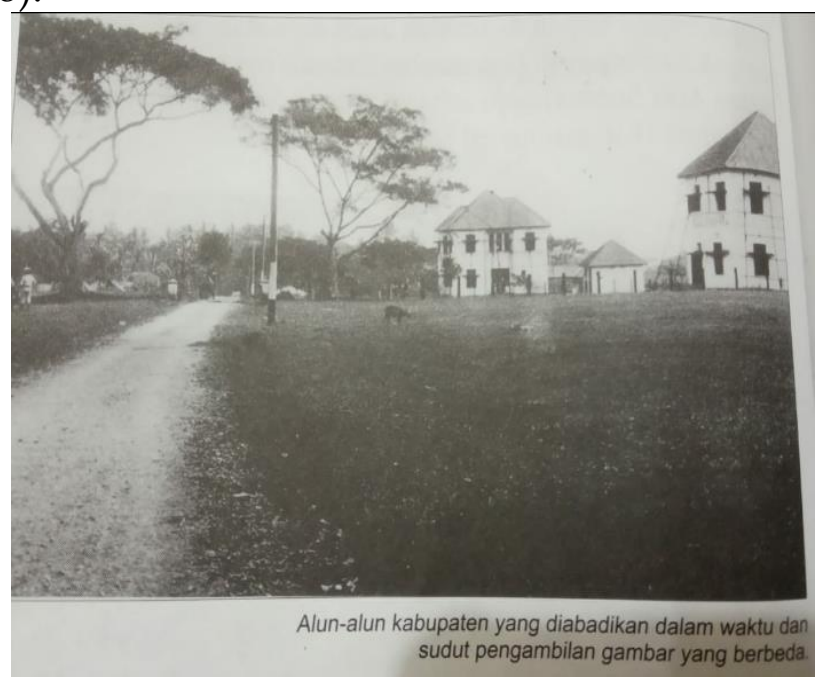

Figure 1. Vacantie-Oord villa building (1919-1986) to the west of the Salatiga Square. Source: (Supangkat, 2007) 


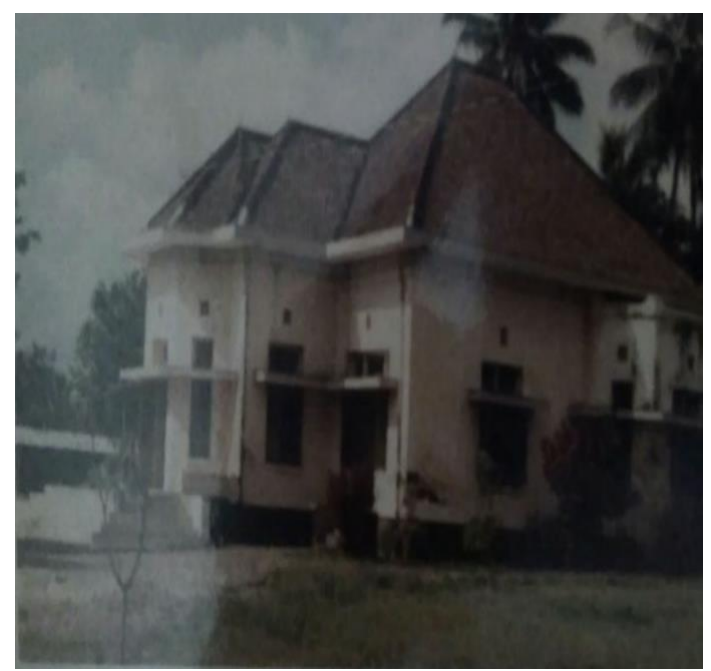

Figure 2. The building of the former villa Vacantie-Oord (1919-1986).

(Source: Photo document at the IAIN Salatiga Library)

\section{Signals of Change}

Signals of changing the landscape of the government center of Salatiga City began to appear since the Salatiga Islamic community formed the Grand Mosque construction committee. In August 1985, the signal became clearer when the Grand Mosque construction committee sent a letter requesting land exchange to the Chancellor of IAIN Walisongo Semarang on September 17, 1985. The content of the letter was a request that the Chancellor of IAIN Walisongo be willing to exchange a portion of the IAIN Salatiga's land for a state-owned land (Letter of the Grand Mosque Construction Committee, 1985).

The Chancellor approved the mosque construction committee's request (IAIN Walisongo Semarang Chancellor's Letter, 1985). There are several reasons for the agreement: First, IAIN is committed to realizing the ideals of the scholars to build a representative mosque in the government center like in several cities in Java (Dahlan, 2017). Second, IAIN did not have a mosque in 1985, while it had a total of 530 lecturers, staffs, and students (Committee for Compiling Book Memories of IAIN Walisongo, 1990). They still used the office space for daily prayers (Karjan, 2018). They also still went to other mosques for the Friday prayer. Third, IAIN did not have an alternative source of funds to build a mosque. The funding priority was still for the development of learning facilities and infrastructure. Fourth, the mosque was going to be built in the land of IAIN $\left(200 \mathrm{M}^{2}\right)$ and the government would replace it with a wider land $(3000$ $\mathrm{M}^{2}$ ). The location of the replacement land was still close to the land of IAIN. Fifth, the people living close to IAIN did not yet have a representative mosque to carry out the Friday prayer and daily prayers, such as the Jangkungan, Karanganyar, Kalinongko, and Kridanggo communities (Oetomo, 2017).

\section{The Symbiotic Role of YAMP, Golkar, Scholar and Government}

The construction of the Salatiga Grand Mosque, besides having opportunities and fulfilling formal requirements, it was also supported from the scholars and the government. The government supported the construction of the mosque indirectly through the Pancasila Muslim Charity Foundation (YAMP). 
Transformation of Villas to Mosques Social Impact of Islamization On The Government Center of Java In The Late $20^{\text {th }}$ Century

Since its establishment in 1982, YAMP is not a government institution, but is led by the President of the Republic of Indonesia on an ex-offisio basis (Taba, 1996). The authority of the President in the government at that time had a centralistic pattern (Karim, 1999). According to the laws of the Republic of Indonesia Number 5 of 1974, the mayor, regent, and governor were appointed directly by the President, not elected through the Regional head election mechanism like now. They and their subordinate officials supported the YAMP effectively. The government support for the YAMP became the sign of change in the political policies of the New Order regime towards Muslims. The policy that was originally antagonistic was changed to critical reciprocity (1982-1985). Starting in 1985, the New Order regime changed its political policies to be accommodative. The New Order government in the antagonistic era tightly controlled the political movements of Muslims (Taba, 1996). They were marginalized in government (Karim, 1999). Muslims also felt attacked by their religious beliefs (Efendy, 1998). In the era of critical reciprocity, the government and Muslims began the process of mutual learning and understanding of each other's position. In the accommodative era, the government did symbiosis with Muslims. YAMP was one of the instruments of the New Order government to explore the response of Muslims to government programs in the era of critical reciprocity. The response of Muslims towards YAMP was so strong that the government continued its policy pattern to be accommodative. One indication of the response was a request to YAMP to build mosques throughout Indonesia (Taba, 1996)).

The Grand Mosque of Salatiga was part of the Muslim strong response to the YAMP. They submitted a request that the YAMP establish a mosque to the west of the central square of the government, so that the landscape could change like the landscape of the Muslim city in Java before. To build the mosque, it required the approval of the YAMP and the government of Salatiga City. The government has the authority that YAMP does not have e.g. land exchange (Letter of Secretary of the Chancellor of IAIN Walisongo, 1986), write-off of state assets (Letter of Minister of Finance, 1986), determination of the feasibility of government buildings (Decree of the Chancellor of IAIN Walisongo, 1986), and the decision to dismantle government offices (Appendix (Minutes), 1986). YAMP was able to establish the Grand Mosque of Salatiga, which was not politically free. There was a political symbiosis between the Salatiga scholars and the New Order government. This phenomenon can be seen in its pioneer affiliated to Golongan Karya (Golkar). For example, the Chairperson of the construction committee was the Retired Lieutenant Colonel Katiman, the Chairman of the Golkar Regional Leadership Council (DPD) of Salatiga in 1984-1989. He moved to build the mosque after the discussion with Drs. Achmadi as the Dean of Tarbiyah Faculty of IAIN Walisongo in Salatiga and Golkar Board of Trustees of Salatiga in 1985-1989 (Widarso, 2018). From the Muslim Military and Academic figures, the idea of building a mosque inspired several Muslim figures in Salatiga like Moch Amin Hambali as the Head of the Ministry of Religion Office of Salatiga Municipality and the Head of Election Winning Strategy of Golkar Salatiga, Kyai Haji Zubair as a scholar and the figure of Golkar in Central Java (Widarso, 2018), H. Muslim Jawahir, H. Sofwan Achmadi, Mansur, Odjie Zainudin, and Khumasi Khumaidi. They were the members of a Golkar subordinate organization, the Islamic Da'wah Council (MDI) or the Indonesian Islamic Education Reform Movement (GUPPI) (Bahrudin, 2018). 
Transformation of Villas to Mosques Social Impact of Islamization On The Government Center of Java In The Late $20^{\text {th }}$ Century

The position of Golkar in Salatiga was very strong in 1984-1986. There were 12 Golkar representatives in the Regional Assembly in Salatiga out of 20 seats. The ABRI faction had 3 representatives, the faction of Partai Persatuan Pembangunan had 2 representatives, and Partai Demokrasi Indonesia had 3 representatives. Golkar's political power in the parliament was getting bigger when the members of Golkar and ABRI factions collaborated (BPS Statistics Office of the Salatiga Municipal Committee, 1986). The mayor of Salatiga, Doelrachman Prawirosoediro, was involved in the administrative process of building the Grand Mosque. Important documents relating to the process of releasing the IAIN land were completed by the Mayor (letter of the Mayor of the Second Level Regional Head of Salatiga, 1986).

The non-Muslim figures of Golkar in Salatiga did not oppose the construction of the Grand Mosque either. For example, John Manuel Manoppo, a Christian, served as Secretary of the Regional Assembly of Golkar in Salatiga. He supported the Golkar leadership in the mosque construction program. Islamic leaders in Partai Persatuan Pembangunan also supported the construction of the Grand Mosque (Widarso, 2018).

\section{Post-Islamization Conditions}

The symbiotic strength of the YAMP, Golkar, Scholars and the Government had really changed the landscape of the government center in Salatiga. The change began with the groundbreaking on August 1, 1986. The Governor of Central Java was present to lay the cornerstone on behalf of $\mathrm{H}$. Soeharto (President of the Republic of Indonesia) as chairman of the Pancasila Muslim Charity Foundation (YAMP) (letter of the Mayor of the Second Level Regional Head of Salatiga, 1986). The event was attended by the committee, public figures, government officials, general students, and madrasah students (Masykur, 2018). When the groundbreaking took place, the Tarbiyah Faculty Office (originally the Vacantie-Oord villa building) was still standing. On August 21, 1986, the Mayor of Salatiga, on the verbal instructions of the Governor of Central Java, ordered the committee to immediately demolish the building so that the construction process could be completed on time (Letter of the Mayor of the Second Level Regional Head of Salatiga, 1986).

The former Tarbiyah Faculty Office building was demolished in September 1986, so that anyone who came to the Pancasila square in October 1986 no longer witnessed the Vila Vacantie oord building or the Tarbiyah Faculty Office of IAIN Walisongo Salatiga. They can only see one building similar to the west. Until now, this building has been used as the office of Salatiga Christian Vocational High School (Saerozi, 2017). On the land of the former Vila Vacantie oord, was built the Grand Mosque or the Great Mosque. It normatively has different criteria from the general mosques. The mosque is a place of worship that meets the requirements and is used for the Friday prayer. The Grand Mosque has more complex criteria compared to general mosques. It must meet three criteria. First, the location of the mosque must be in the municipal capital. Second, the mosque should be managed by the municipal level Islamic scholar. Third, the mosque received guidance from the Department of Religion (Amidhan \& Fathuddin, 1981/1982).

The Grand Mosque was built with a full package model from YAMP. The size, architectural design, and funds of the mosque were uniformly determined by YAMP. The mosque has the size of $19 \times 19 \mathrm{M}^{2}$ with a three-tiered joglo-shaped roof. On the roof 
Transformation of Villas to Mosques Social Impact of Islamization On The Government Center of Java In The Late $20^{\text {th }}$ Century

is a pentagonal star symbol. The pentagon symbolizes Pancasila. Inside the pentagon symbol is the Arabic inscription "لال山". According to Shihab (2014), this architectural design adopts the symbolization of mosques in Java in the past, such as Demak mosque. The construction process of the mosque lasted almost 1 year. The ceremonial inauguration of the mosque was carried out by the Minister of People's Welfare (Soerono) in July 1987 (Zuhri, 2017).

The mosque was named Darul Amal (دار العمل). However, there is different opinion in interpreting the name because it written with Latin words "Darul Amal" without any Arabic translation. As an Arabic linguist, Maesur (2018) argues that the name is الار (the home of hope), but Kuswaya (2018) interprets the names as دار العمل (the home of work). Muhson (2017) as the witness of the history explains that the most relevant name is دار العمل. Such name is coherent with the sponsor politic affiliation namely Golongan Karya (Golkar). In addition, the Arabic dictionary mentions the term دار can be translated into English as tribe or group (Yunus (t.t.). The term العمل means work in English. Darul Amal (دارالعل means "Golongan Karya (Work Group)". Since the inauguration of the Grand Mosque, the landscape model of the government center of Salatiga has completely changed. The government center was no longer in Dutch nuance, but it had changed its model to the Muslim cities in Java. The square was in the center, the government center in the southeast, the church in the east, the police station in the north, and the Grand Mosque in the west.

The status of the Grand Mosque belonged to the Salatiga City Government even though the land certificate was still in the name of the Ministry of Religion. The management of the mosque was on IAIN Salatiga. The management involves the lecturers, Ministry of Religion officials and surrounding public figures. The $t a^{\prime}$ mir chairman of the mosque was Dr. Muh Zuhri (Zuhri, 2017). The mosque is used for religious and educational activities, such as learning Qur'an for children, recitation to commemorate Islamic holidays, and recitations. There are also religious lectures after the midnight prayers in Arabic and English (Mariana, 2018). The funds for mosque activities and maintenance are sourced from infaq, zakat and other donations. Muh Zuhri stated that the government had never specifically provided subsidy for the development of mosque activities, mosque operational funds, and maintenance (Zuhri, 2018).

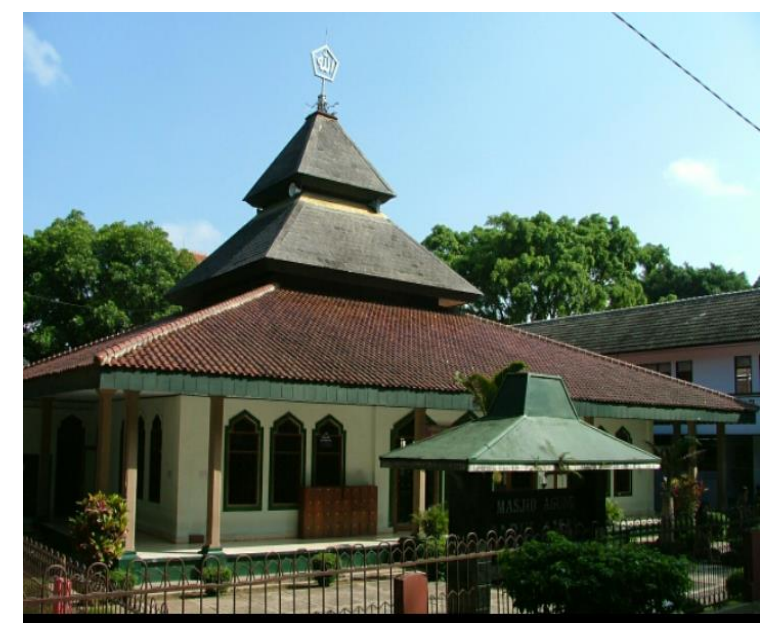

Figure 3. The Grand Mosque Darul Amal ( دار العمل) Salatiga 1986-2009. (Source: Photo document at the IAIN Salatiga Library) 
Transformation of Villas to Mosques Social Impact of Islamization On The Government Center of Java In The Late $20^{\text {th }}$ Century

\section{Renovation Era}

Darul Amal Mosque was completely renovated starting in early 2009, but the renovation initiative has been in place since early 2007. According to the Chairman of Indonesian Islamic Scholar Council (MUI) Salatiga, the renovation initiator was John Manuel Manoppo, Mayor of Salatiga for the 2007-2011 period. John Manuel Manoppo is a Christian born in Kulawi Manado. He delivered the mosque renovation initiative in the opening ceremony of the Regional Forum of MUI of Salatiga on March 23, 2007 (Zuhri, 2018).

The Salatiga Mayor's initiative was not only to renovate the Darul Amal mosque, but also to build an Islamic center. The Islamic center complex can be used for education, religion, and business purposes. The desired location is the Salatiga Resort Police Station complex. The initiative to build an Islamic center was changed due to differences of opinion between the Mayor, MUI, and the police. The idea of building an Islamic center was replaced by renovating the Darul Amal mosque. MUI followed up on the Mayor's initiative through its 2007-2012 program. The Chairman of MUI Salatiga noted that one of the programs was Building the Grand Mosque of Salatiga City on the initiative of Mayor John Mapopo in the 2007 MUI Regional Forum to set up a grand mosque like in Semarang, which occupies the location to the west of the Pancasila square (MUI of Salatiga City, 2013).

The explanation of the chief of MUI Salatiga concludes the debate on motive and the initiator of the Grand Mosque renovation of Darul Amal. For example, Suaidi (2018) as a Moslem scholar Salatiga and Mahasin (2018) as the treasure of Darul Amal mosque provide an insight that the renovation is as the strategy of vice mayor of Salatiga, John Manuel Manoppo, to hush disappointment of some groups of Moslems. Such perspective emerged because there was a huge movement of Moslem in 2007 in Salatiga and affected the politics of the Mayor and interreligious stability. The movement took into action by the Moslem united in Yayasan Umat Islam Salatiga (YUIS). The target of YUIS is to acquire 50 Ha land managed by Yayasan Kristen Salib Putih. Cultivation Rights Title will be ended in December 2007, so the movement conducted beforehand. However, YUIS was fail to acquire the land of Salib Putih, because in October 2007 the office of BPN (Indonesian National Land Office) Regional Central Java decided that 89 Ha land of Salib Putih remained on the possession of Yayasan Rumekso Mekaring Sabdo (RMS) and Gereja Kristen Jawa (GKJ) (Seo, 2014).

The main purpose of renovation is to magnify and expand the Grand Mosque to make its performance more artistic and accommodate more worshipers. This purpose is in accordance with the reality of the Darul Amal Mosque that has not met the expectations of all parties. For example, the floor position of the mosque is lower than that of the road and the square, so that its performance appears to be drowned among other buildings (Zuhri, 2018). Myengkyo Seo as an outside researcher also considered that the most prominent building around the square was the synod of the Central Java Christian Church (GKJTU). He also informed that some Muslims regretted that the church is bigger than the mosque (Seo, 2014).

Efforts to renovate the mosque could not be carried out immediately due to the problem of land status. The Darul Amal Mosque, which was inaugurated in July 1987, belongs to the Salatiga city government, but the government had held a non-certificate for 22 years. The government only had a letter of removal of buildings from the 
Transformation of Villas to Mosques Social Impact of Islamization On The Government Center of Java In The Late $20^{\text {th }}$ Century

Indonesian Minister of Religion in 1987. The letter did not include the number, date, and seal of the Ministry of Religion (Decree of the Minister of Religion, 1987).

The committee's concentration at the initial stage was to finalize the land status in coordination with the Head of STAIN Salatiga. The Mayor of Salatiga sent a letter to the Head of STAIN Salatiga in February 2008 to help resolve the issue of land status (Letter of the Mayor of Salatiga, February 6. 2018). The Mayor resent his letter in September 2008 (Salatiga Mayor's Letter, September 10, 2018). While waiting for a complete letter from the Ministry of Religion, the renovation process began in early 2009. The Solo Pos newspaper on February 21, 2009 reported that the Grand Mosque Darul Amal had been demolished, leaving only the frame. The Salatiga city government funded renovation (Triyono, February 21, 2009). The construction process was supposed to be completed on September 15, 2009, but the tower building had not been completed until April 2010 (Suara Merdeka, Monday, September 20, 2010.

The Salatiga City government allocated another 2.5 billion in the following year to complete the tower (Solo Pos, Thursday, April 22, 2010). The total funding for the mosque's construction was 10.7 billion (Seputar Indonesia, October 19, 2010). The delay in the development process resulted in a new tension in Salatiga because it involved the legal sphere and the news was spread to the mass media (Suara Merdeka, September 20, 2010).

The mosque, which was renovated starting in early 2009, was finally inaugurated on February 27, 2013. The land certificate process was completed in 2010 (Rokhati, 2018). The mosque was renovated during the era of Mayor John Manuel Manoppo, inaugurated on February 27, 2013 by the new Mayor of Salatiga, Yulianto (Inscription of Darul Amal Mosque Salatiga).

The volume of the mosque after the renovation was greater than that of the YAMP mosque. The new mosque building was built on all available land while the old mosque still had an open space in the front and right sides. The new mosque architecture design is also different from the YAMP mosque. The old mosque had one floor while the new mosque has two. The old mosque floor position was lower than the road and the Pancasila Square, so people who stood on the terrace of the mosque found it difficult to watch the conditions on the Pancasila Square. The new Grand Mosque has 2 floors, so the position of the floor for prayer is higher than the road and the square. When people are on the second floor, they can see the Pancasila Square as a whole.

The first floor of the mosque is used for offices, meeting rooms, study rooms, warehouses, and places for ritual ablution. The second floor is for male congregational prayers. The balcony on the third floor is used for prayers for female worshipers. The new mosque roof model uses a dome. The domed mosques inherit Middle Eastern and European mosques, such as the Ash-Shakhra Dome in Baitul Maqdis, the Sultan Ahmad Mosque dome in Istanbul, the domes of the Astanah Mosque in Cairo, and the domes of buildings in Andalusia (As-Sirjani, 2011). The old mosque used a three-tiered Joglo model. This model inherits the cultural value of mosques in Indonesia in the past. 


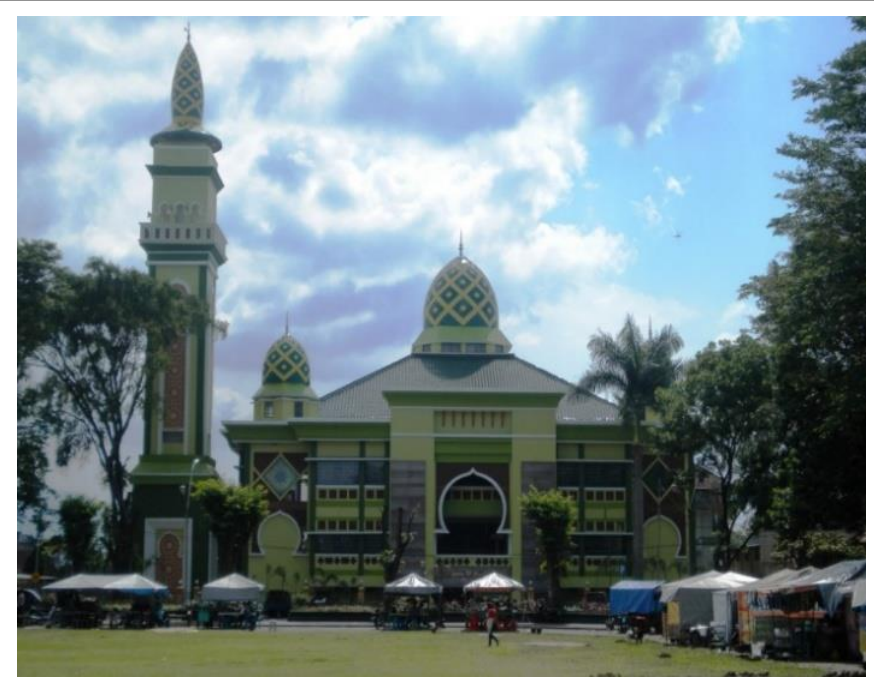

Figure 4. The Grand Mosque Darul Amal (دار العمل) Salatiga after renovation in 2009present (Source: Photo document at the IAIN Salatiga Library)

\section{Impact of Islamization}

The landscape of the Salatiga government center becomes Islamic with the building of the Darul Amal Mosque to the west of the square, but it has limited spiritual and social impacts. For example, the echoes of the call to prayer were heard clearly 5 times a day, but only a small number of Muslims in the square and its surroundings rushed to the mosque. This phenomenon can be seen from the comparison of the number of worshipers having a midday prayer and the number of people around the government center. On average, there are 150 people praying while more people are still around the mosque. $60 \%$ of the midday-prayer worshipers are lecturers, students, and employees of IAIN (Ni'am, 2018).

Activities in the mosque in general are still the same as those in the old one. The routine activity at the Darul Amal Mosque since 2012, in addition to the five daily prayers and the Friday prayer, are recitation. The types of thought in the recitation, borrowing Muhaimin's opinion, can be divided into neo modernist and salafi textualist categories (Muhaimin, 2011). The first is the Mawar Allah recitation under the guidance of Mr. Ahmad Sultoni. This ustadz has neo-modernist thinking. The participants of the recitation consist of high-school and vocational-school students in Salatiga City. The average number of the worshipers is 1000 people. The second is the Muslimah recitation followed by women of the Salafi intellectual type. The third is the Al-Kahfi recitation which is of a salafi textual type. The ustadz is from the Al-Irshad institution. This recitation is carried out routinely every Friday after the afternoon prayer. Most of the recitation participants are from SMA 3 alumni. The fourth is AlQur'an learning for children. The recitation is conducted every afternoon. The TPQ teachers are Salatiga IAIN students. TPQ recitation participants are children of around the mosque. On average, there are around 50 children present (Ni'am, 2018). Another impact of Islamization is harmonization in the landscape of the government center. Before the 1986 era, the government center was only equipped with a church. Now, the government center also has a mosque. The church is to the east of the square and the mosque is to the west. 


\section{CONCLUSIONS}

Based on the results and discussion, we can draw conclusions as follows: The Islamization of the Salatiga government center was carried out because its infrastructure was still European patterned. This condition does not support the actualization of Muslim religiosity at the government center. The first stage of Islamization was marked by by replacing the former villa building into a mosque. The design of the mosque and its funds came from the Pancasila Muslim Charity Foundation (YAMP). The first stage of Islamization was successful because of the symbiotic factors of the Pancasila Muslim Charity Foundation (YAMP) with the political power of Golkar, Salatiga scholars, and the Salatiga City Government. The second stage of Islamization was successful because it was supported by the Salatiga Mayor and the Indonesian Islamic Scholar Council (MUI) in Salatiga. The landscape of the Salatiga government center becomes Islamic with the building of the Darul Amal Mosque to the west of the square, but it has limited spiritual and social impacts. However, Islamization has had a harmonious impact on the landscape of the government center. This research can be continued with the harmonization of religious life in Salatiga as a form of the city of tolerance in Indonesia.

\section{ACKNOWLEDGEMENTS}

This study was funded by a research and community service institute of Institut Agama Islam Negeri (IAIN) Salatiga. Thanks to Salatiga government for supporting data this research.

\section{REFERENCES}

Amidhan, H., \& Fathuddin. U. (1981) Pedoman pembinaan masjid. Jakarta: Ditjen Bimas Islam dan urusan Haji Direktorat Urusan Agama Islam 1981/1982.

Ashadi. (2017). Alun-alun kota Jawa. Yogyakarta, Arsitektur UMY Press.

As-Sirjani, R. (2011). Sumbangan peradaban Islam pada dunia, translated by Sonif, Mastuti Irham, dan Malik Supar. Jakarta: Pustaka Al-Kautsar.

Azra, A. (2013). Islamisasi Jawa, Book Review. Studia Islamika , 20 (1), 169-170.

Bahrudin, A. (64 years old). (2018). Interview. on January 9, 2018.

Dahlan, L. (72). (2017). Retiree of IAIN Salatiga staff. Interview. on July 12, 2017.

Damayanti, R., \& Handinoto, (2005). Kawasan pusat kota dalam perkembangan sejarah perkotaan di jawa. Dimensi Teknik Arsitektur, 33 (1), 39-45.

Efendy, B. (1998). Islam dan negara: Transformasi pemikiran dan praktik politik Islam di Indonesia. Jakarta: Paramadina.

Karjan (51 years old). (2018). Finance Staff of IAIN Salatiga. Interview. on Sunday, February 25, 2018.

Karim, M.R. (1999). Negara dan peminggiran islam politik. Yogyakarta: Tiara Wacana.

"Kajari: Ada Penyimpangan Proyek Masjid Raya", Solo Pos, Thursday, May 6, 2010.

"Kasus Masjid Raya ditangani Kajari Jateng, Suara Mereka, Monday, September 20, 2010.

"Kasus Masjid Raya Ngambang", Seputar Indonesia, October 19, 2010.

“Kasus Majid Raya ditangani Kajati Jateng, Suara Merdeka, September 20, 2010.

Kuntowijoyo. (2008). Penjelasan sejarah. Yogyakarta: Tiara Wacana. 
Transformation of Villas to Mosques Social Impact of Islamization On The Government Center of Java In The Late $20^{\text {th }}$ Century

Lampiran (Berita Acara) Surat Panitia Penelitian dan Penghapusan Gedung Kantor Fakultas Tarbiyah IAIN Walisongo di Salatiga No. 01/PAN/VII/1986 tentang Laporan Kepada Rektor IAIN Walisongo di Semarang tanggal 22 Juli 1986.

Kuswaya, A. (46 year Old), Lecturer of IAIN Salatiga, interview on January 5, 2018

Machrus. (2008). Simbol-simbol sosial kebudayaan Jawa, Hindu dan Islam yang direpresentasikan dalam artefak masjid agung Surakarta. Thesis: Postgraduate of Sebelas Maret University, Surakarta.

Maesur, S. (56 year Old). (2018). Lecturer of IAIN Salatiga. Interview. on January 5, 2018

Mariana, A. (52 years old). (2018). Interview on January 24, 2018. Interview. on January 25,2018

Masykur (51 years old). (2018). Alumni of Islamic Teacher Education Salatiga, interview on January 25, 2018.

Moleong, J. L. (2014), Metodologi penelitian kualitatif. Bandung: Remaja Rosdakarya.

Muhaimin. (2011). Pemikiran dan aktualisasi pengembangan pendidikan Islam. Jakarta: Rajawali Press.

Muhson, A, (68 year old). (2017). Former chief of Religious court of Salatiga. Interview. on July 22, 2017.

Mahasin. (2018). The treasurer of Darul Amal mosques in the period of 2012-2017, , interview on May 25, 2018.

MUI Kota Salatiga. (2013). Laporan Kegiatan MUI Kota Salatiga sesuai dengan Komisi Baik yang Tercapai Maupun Belum Periode Tahun 2007-2012. Salatiga: MUI.

Ni'am. (2018). Staff of Darul Amal Mosque, interview on October 16, 2018.

Oetomo, SH. (79 years old). (2017). Public figure in the Jangkungan Salatiga neighborhood, interview on July 22, 2017.

Omar. (2017). The Impact of Islamization on Income Inequality and Economic Growth Nexus in Malaysia. International Journl of Applied Business and Economic Research. 1 $15,61-80$.

Panitia Penyusun Buku Kenang-Kenangan IAIN Walisongo. (1990). Kenangan Dwidasawarsa IAIN Walisongo, Semarang: IAIN Walisongo.

Parmadi. A. (2013). Monumen perjuangan salatiga: Potret heroik pahlawan salatiga. Salatiga: Griya Media.

Pijper, G. F. (1985). Beberapa studi tentang sejarah islam di indonesia 1900-1950. Jakarta: UI Press.

Prakosa, A. J. (2017). Diskriminasi rasial di kota kolonial: Salatiga 1917-1942. Salatiga: Sinar Hidoep.

Proyek Masjid Raya Salatiga diduga Bermasalah. (2010). Solo Pos. Thursday, April 22, 2010.

Ramdlani, S. (2010). Kedudukan dan fungsi masjid agung terhadap alun-alun Kota Malang. Journal of Islamic Architecture. 1 (1), 8.

Ridwan, B. (2011). Potret Organisasi Keagamaan dan Respon terhadap Dinamika Kehidupan Keberagamaan di Salatiga. Jurnal Inferensi. 5 (1), 111-118.

Rokhati, D. (2018). Head of Staffing and General Affairs Division of IAIN Salatiga. Interview. on January 23, 2018.

Seo, M. (2014). The White Cross in Muslim Java: Muslim-Christian Politics in the Javanese City of Salatiga. in Islam and Christian-Muslim Relations. 25(3), 1-11. 
Transformation of Villas to Mosques Social Impact of Islamization On The Government Center of Java In The Late $20^{\text {th }}$ Century

Sertifikat Tanah Bukti Hak Pakai. (1982). Desa Mangunsari Kotamadya Salatiga, Hak Milik No. 30, Jalan Caranggoto, No seri. 5997456. Surat Keputusan Gubernur Kepala Daerah Propinsi Jawa Tengah No. DA.II/HP/ 322/1/2443/1982 on September 2, 1982. Kantor Agraria Kotamadya Salatiga, on September 23, 1982.

Simas. Kemenag. (2018). Profil Masjid.

Simbolon, P. T. (1995). Akar-akar kebangsaan Indonesia. Jakarta: Kompas-Grasindo.

Soediyono. (1986). Berita Acara Penelitian Gedung Kantor Fakultas Tarbiyah IAIN Walisongo di Salatiga. Arsip Surat. Salatiga, Fak. Tarbiyah IAIN Salatiga, p. Appendices.

Suaidi, A. A. (45 Year old). (2018). Moslem scholar of Salatiga. Interview. on June 6, 2018.

Subadi. (2018). Retiree IAIN Salatiga Staff, interview on April 8, 2018.

Supangkat, E. (2007). Salatiga sketsa kota lama. Salatiga: Griya Media.

Supangkat, E. (2010). Galeria Salatiga. Salatiga: Griya Media.

Supangkat, E. (2017). Istana Djoen Eng Jejak Etnis Cina di Salatiga. Salatiga: Dinas Perpustakaan dan Kearsipan Daerah Kota Salatiga.

Supangkat, E. (2017). Gedung pakuwon. Salatiga: Dinas Perpustakaan dan Kearsipan Daerah Kota Salatiga.

Surat Panitia Pembangunan Masjid Raya Kotamadya Salatiga, tentang Tukar tanah milik IAIN dengan tanah Negara untuk Masjid Raya, nomor 05/ Pan. /MR/IX/ I85, tanggal 17 September 1985)

Surat Rektor IAIN Walisongo Semarang No. 981/A-a/WS-0/X/ 1985 tentang Tukar Tanah Milik IAIN dengan Tanah Negara untuk Masjid Raya, tanggal 21 Oktober 1985.

Surat Sekretaris Rektor IAIN Walisongo Semarang Nomor 552/ C-a/WS-0/IV/ 86 tentang Penyelesaian penukaran Tanah untuk Masjid Raya Salatiga, tanggal 19 April 1986.

Surat Menteri Keuangan RI No. S-1038/ MK.011/ 1986 perihal Penghapusan gedung Kantor Fakultas Tarbiyah IAIN-Walisongo Salatiga beserta tanahnya tanggal 15 September 1986.

Surat Keputusan Rektor IAIN Walisongo No. 142/ 118/ B.a.1/ WS-0/ VI/ 1986 tanggal 30 Juni 1986.

Surat Walikotamadya Kepala Daerah Tingkat II Salatiga No. 011/ 594, tentang Permohonan pembongkaran Kantor Fakultas Tarbiyah di Salatiga, tanggal 28 Juni 1986.

Surat Walikotamadya Daerah Tingkat II Salatiga nomor 642/ 1172, tentang Pembongkaran Bangunan, tanggal 21 Agustus 1986.

Surat Walikota Salatiga Nomor 594.3/ 249 perihal Pensertifikatan tanah Masjid Raya "DARUL AMAL" Salatiga, tanggal 6 Februari 2008.

Taba, A. A. (1996). Islam dan negera dalam politik orde baru. Jakarta: Gema Insani Press.

Tjandrasasmita, H. U. (2000). Pertumbuhan dan Perkembangan Kota-kota Muslim di Indonesia sejak abad ke-XIII sampai dengan abad ke-XVIII. Kudus: Penerbit Menara Kudus.

Triyono, E. (2009). Kerangka. Solo Pos, February 21, 2009

Undang-undang Republik Indonesia Nomor 5 tahun 1974 tentang Pokok-pokok Pemerintahan di Daerah 
Transformation of Villas to Mosques Social Impact of Islamization On The Government Center of Java In The Late $20^{\text {th }}$ Century

Wasino \& Endah, S. H. (2018). Metode Penelitian Sejarah: dari Riset hingga Penulisan. Yogyakarta: Magnum Pustaka Utama.

Widiarto, T., \& Saparus, K. (2015). Menguak Perjanjian Salatiga 17 Maret 1759: Perspektif Historis. Salatiga: Wisyasari.

Widarso, G. (2018). Former Golkar deputy secretary in Salatiga. Interview. on January 27, 2018.

Zuhri, M. (2017). Former Head of Sekolah Tinggi Agama Islam Negeri Salatiga. Interview. On Thursday, July 20, 2017.

Zuhri, S. (2018). Chairman of Majelis Ulama Indonesia Kota Salatiga in 2007-2012. Interview. On July 6, 2018.

\footnotetext{
* Prof. Dr. Muh Saerozi, M.Ag. (Corresponding Author)

Magister Program of Islamic Religious Education

State Institute of Islamic Studies (IAIN) Salatiga, Indonesia.

Jl. Lingkar Salatiga KM 2 Pulutan, Sidorejo, Kota Salatiga, Provinsi Jawa Tengah Indonesia.

Email: saerozi2010@yahoo.com
} 